\title{
RESPONSE OF BARKI LAMBS TO DIETS CONTAINING CASSAVA AND TREATED WHEAT STRAW WITH PROSOPIS OR ACACIA SALIGNE (LEAVES \& TWIGS) UNDER SEMI-ARID AREA IN EGYPT
}

\author{
M. M. Eissa, A. EL-Wakeel. EL., A. M. Saber, A. R. Khattab and W. M. A. Sadek \\ Animal Production Research Institute, ARC, Dokki, Giza, Egypt \\ SUMMARY
}

This work carried out on growing Barki lambs to investigate the effect of using different combination from Cassava, Acacia Saligne and Prosopis (leaves \& twigs) with treated wheat on growth performance, feeding values and feed utilization efficiency. Thirty lambs aged about 3 months and weighed in average $11.93 \pm 0.40 \mathrm{~kg}$ were divided randomly into three groups, 10 lambs each. The supplementary values of two tree fodder with treated wheat straw were concluded that in complete rations as follow:

(G1) Control CFM+ berseem (Trifolum alexandrinum) hay.

(G2) CFM+ Cassava: Acacia Saligne: treated wheat straw at) 37.5: 37.5: 25, respectively).

(G3) CFM+ Cacaav: Prosopis: treated wheat straw at (37.5: 37.5: 25, respectively).

The roughage to concentrate ratio was maintained at 60:40 so as to meet the nutrient requirement (NRC, 1985) for growing sheep. The feeding trials lasted for 16 weeks.

The obtained data indicated that the methane production with first combination Cassava: Acacia Saligne: treated wheat straw 37.5: 37.5: 25 less than second combination Cassava: Prosopis: treated wheat straw 37.5: 37.5: 25 (8 vs.10ml/200 mg DM, respectively). Whereas, first combination was

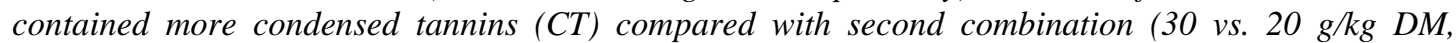
respectively). The results indicated that most tested blood parameters were not significantly affected by tested rations. However, serum total protein (TP), albumin $(A)$ and globulin $(G)$ concentrations were tended to decrease with $G 2$ and $G 3$ compared with $G 1$, but $A / G$ ratio was increase with the combination of two fodder tree with wheat straw ammoniated (G2 and G3) without significant differences. While, glucose, serum urea, creatinine and cholesterol were significantly higher $(P>0.05)$ with (G1) berseem hay (60.10, 46.26, 1.95 and 72.08, respectively) in Barki lambs rations. The highest values of final body weight $(F B W)$ and total body gain $(T B G)$ were recorded with $G 2(34.44$ and 22.20 $\mathrm{kg}$, respectively) and the lowest values was detected with $G_{3}(31.33$ and $19.80 \mathrm{~kg}$, respectively). Whereas, $G_{1}$ recorded medium values $(33.52$ and $21.24 \mathrm{~kg}$, respectively). Thus, the daily body gain $(D B G)$ was significantly increased $(P<0.05)$ in Barki lambs fed $G 2$ than the other groups G1 and G3. Feed conversion calculated as dry matter intake and CP intake/kg gain were better in G3 (4.01 and 0.618 , respectively) compared with $G 2$ (4.67 and 0.678, respectively) and G1 (4.84 and 0.707, respectively) but the differences were not significant. The economic efficiency (EE) was better with G3 then G2 compared with G1. These results indicated that under the semi-arid conditions, the combinations of Cassave and ammoniated wheat straw along with Prosopis Juliflora or Acacia Saligne could be included up to $60 \%$ in the complete diet of growing Barki lambs.

Keywords: Cassava, prosopis, acacia, economic efficiency, growing lambs, Barki

\section{INTRODUCTION}

The North Western Coast of Egypt stretches along $525 \mathrm{~km}$ on the Mediterranean Sea, west of Alexandria city latitudes $21^{\circ}$ and $31^{\circ}$ North and longitudes $25^{\circ}$ and $35^{\circ}$ East, the average temperature ranges from $13^{\circ} \mathrm{C} \quad\left(56^{\circ} \mathrm{F}\right)$ in December and January to $26^{\circ} \mathrm{C}\left(79^{\circ} \mathrm{F}\right)$ in July and August. This promising region has little effective rainfall, Except for the areas along the Mediterranean coast, where winter rains are frequent, rainfall in Egypt's harsh desert climate is scarce to nonexistent, during the summer months and even the coast receives little or no rain. As a result, droughts and windstorms called (khamasin) occur often. The Western Desert accounts for almost three-fourths of the total land area of Egypt. In general the climate of this region is arid Mediterranean with a scarcity of rain and high radiation. The atmospheric relative humidity ranges from $50 \%$ to $75 \%$ and the average annual rainfall is about $100-150 \mathrm{~mm}$, distributed over a period of 15-25 rainy days during the wet season. The suitable halophytic forage species that show better adaptability and chances of establishment are Cassava, Acacia saligne and Prosopis juliflora (Degan et al., 1997; Shawket, 1999 and Khang et al., 2005). In the desert rangelands, 1.4 million sheep and goats are kept in extensive systems. Sheep are mainly of the fat-tailed, coarse-wool, Barki breeds, Goats are mainly hairy and of medium size, and they vary greatly in type and 
productivity, the lighter Barki breed in the northwest coastal area. Therefore, the main objective of the present study were to investigate the effect of using different combination from Cassava, Acacia Saligne and Prosopis (leaves \& twigs) with treated wheat straw on growth performance and feed utilization efficiency of Barki lambs.

\section{MATERIAL AND METHODS}

The present study was conducted at Borg El Arab Livestock Research Station, Animal Production Research Institute, Ministry of Agriculture.

\section{Animals and Management:}

Thirty growing male lambs of Barki, aged about 3 months and weighed in average $11.93 \pm$ $0.40 \mathrm{~kg}$ were divided randomly into three groups, 10 lambs each housed separately in shaded pen. The animals were weighed at the beginning then biweekly. The feeding experiment lasted 16 weeks. Barki lambs were fed for 3 weeks as a transitional period on the experimental rations before the start of the experimental work. During that period they were treated with anti-helmenthics.

\section{Experimental treatments:}

Lambs received diets in groups. Barki lambs were fed tested rations accordingly as follow:

(G1) Control CFM+ berseem (Trifolum alexandrinum) hay.

(G2) CFM+ Cassava: Acacia Saligne: treated wheat straw at 37.5: $37.5: 25$, respectively.
(G3) CFM+ Cacaav: Prosopis: treated wheat straw at $37.5: 37.5: 25$, respectively.

The roughage to concentrate ratio was maintained at 60:40 level to meet the nutrient requirement (NRC, 1985) for growing sheep. The level of the ingredients in the concentrate portion was adjusted to maintain iso-protein and isocaloric nature in the experimental rations. The chemical composition of the tested ingredients consumed by Barki lambs is shown in Table (1). Analysis of feed stuffs for micro-minerals, macro-minerals and phenols compound shown in Tables (2 and 3). The mineral content was determined by dry-Ashing the samples at $550^{\circ} \mathrm{C}$ in a furnace, and dissolving the ash in 10\% HCI, and filtered (Oshodi, 1992). Sodium (Na) and potassium (K) were determined by flame photometer while Atomic Absorption Spectrometer (AAS) was used to determine $\mathrm{Ca}$, $\mathrm{Mg}, \mathrm{Zn}, \mathrm{Fe}, \mathrm{P}$ and $\mathrm{Cu}$ (A.O.A.C., 1990). Acid detergent fibre (ADF) and neutral detergent fiber (NDF) were analyzed by the Van Soest method (Van Soest 1965). Anti-nutrients determination: Tannin content was determined using the method described by Makkar (2003). Phytic was extracted and precipitated according to the method of Reed (1995). Quinones and glycosides content were determined using the procedure of Reed et al. (2000). Alkaloid was obtained by Harbone (1973) method while saponin was assayed by the test described by Wilson (1992). Water was available all times. The rations were offered twice daily at $8 \mathrm{am}$. and $3 \mathrm{pm}$.

Table 1. Chemical composition and cell wall constituents (\% on DM basis) of feed ingredients

\begin{tabular}{|c|c|c|c|c|c|c|c|c|c|c|}
\hline \multirow{2}{*}{ Item } & \multirow{2}{*}{$\mathrm{DM}$} & \multicolumn{6}{|c|}{ Chemical composition } & \multicolumn{3}{|c|}{ Fiber Fraction } \\
\hline & & $\mathrm{OM}$ & $\mathrm{CP}$ & $\mathrm{CF}$ & $\mathrm{EE}$ & NFE & Ash & $\mathrm{NDF}$ & $\mathrm{ADF}$ & ADL \\
\hline Berseem hay & 95.12 & 89.59 & 10.64 & 38.54 & 1.03 & 39.38 & 10.41 & 55.89 & 43.27 & 37.16 \\
\hline $\begin{array}{l}\text { Prosopis } \\
\text { Juliflora }\end{array}$ & 70.39 & 93.30 & 17.52 & 30.70 & 2.72 & 42.36 & 6.70 & 57.41 & 42.69 & 39.23 \\
\hline Acacia Saligne & 52.45 & 91.66 & 15.66 & 31.59 & 1.47 & 42.94 & 8.34 & 60.86 & 54.57 & 48.96 \\
\hline Cassava & 44.39 & 88.26 & 22.94 & 28.05 & 2.92 & 34.35 & 11.74 & 35.49 & 26.29 & 19.47 \\
\hline $\begin{array}{l}\text { Treated Wheat } \\
\text { Straw }\end{array}$ & 98.00 & 89.00 & 9.86 & 48.23 & 3.90 & 27.07 & 11.00 & 35.42 & 30.22 & 27.33 \\
\hline CFM* & 91.20 & 93.90 & 15.70 & 14.23 & 3.13 & 60.84 & 6.10 & 43.00 & 17.30 & 5.80 \\
\hline
\end{tabular}

Table 2. Micro and Macro -mineral composition (mg/kg DM) of feed stuffs

\begin{tabular}{cccccc}
\hline Item & Berseem hay & $\begin{array}{c}\text { Prosopis } \\
\text { Juliflora }\end{array}$ & $\begin{array}{c}\text { Acacia } \\
\text { Saligne }\end{array}$ & Cassava & $\begin{array}{c}\text { Treated wheat } \\
\text { straw }\end{array}$ \\
\hline \multicolumn{2}{l}{$\begin{array}{l}\text { Micro-mineral composition } \\
\text { (mg/kg DM): }\end{array}$} & & & & \\
$\mathrm{Fe}$ & 471.2 & 384.1 & 165.87 & 184.05 & 31.57 \\
$\mathrm{Mn}$ & 31.94 & 13.11 & 36.36 & 180.25 & 1.89 \\
$\mathrm{Zn}$ & 30.38 & 44.11 & 38.66 & 108.95 & 47.17 \\
$\mathrm{Cu}$ & 3.4 & 4.1 & 2.5 & 4 & 3.96 \\
$\mathrm{Macro}-m$ & & & & \\
$\mathrm{Na}$ & 1921 & 210 & 953 & 181 & 1817 \\
$\mathrm{Ca}$ & 856 & 506 & 3484 & 2130 & 172 \\
$\mathrm{~K}$ & 1089 & 781 & 201 & 1470 & 189 \\
$\mathrm{P}$ & 340 & 236 & 218 & 266 & 753 \\
\hline
\end{tabular}


Table 3. Phenols compound on dry and wet basis (mg/g) as tannic acid of Certain tree \& shrubs Species

\begin{tabular}{ccc}
\hline Item & Phenolic compound on dry basis & Phenolic compound on wet basis \\
\hline Prosopis Juliflora & 111.89 & 90.36 \\
Acacia Saligne & 108.60 & 91.09 \\
Cassava & 99.729 & 80.22 \\
\hline
\end{tabular}

\section{Feed samples and gas production:}

Three fresh different species leaves \& twigs samples of (Acacia Saligne, Prosopes Juliflora, and Cassava). The collected samples were pooled and then dried in shadow. The samples were then sieved to pass through $1 \mathrm{~mm}$ sieve and stored in airtight polythene bags for further analysis. Similarly, samples of wheat straw were treated by injecting ammonia in the Borg El Arab Livestock Research Station. Samples of feeds were analyzed according to A.O.A.C (1995).

According to previous chemical analysis of three fodders leaves \& twigs viz (Prosopes Juliflora, Acacia Saligne and Cacava) and treated wheat straw were then mixed in different combinations in different proportions and subjected to in vitro dry matter degradability as described by A.O.A.C (1995). This analysis was done to list the optimum tree fodder- crop residue combinations that gave the highest degradability. At the end of this analysis, based on the statistical analysis, a total of two promising combinations to determine methane concentration. The gas was analyzed with a portable GASMET DX4030 gear using the $\mathrm{CO}_{2}$ Technique, which measure the $\mathrm{CO}_{2}$ content and then calculate the ration $\mathrm{CH}_{4} / \mathrm{CO}_{2}$ (Patra et al., 2006).

\section{Blood samples:}

Blood samples were collected from the jugular vein once before feeding ( 3 animals in each) at the end of growing period. Blood samples were centrifuged at $4000 \mathrm{rpm}$ for 20 min. Part of the separated serum was directed to enzymes activity determination, while the other part was stored frozen at-20c till the biochemical analysis. Commercial kits were used for all colorimetric biochemical determination.

\section{Economic efficiency:}

Economic efficiency was calculated, as total output/ total input according to the local prices (where one ton $\mathrm{BH}=1600$ L.E.; CFM $=2800$ L.E.; Cassava $=500$ L.E.; Prosopis Juliflora = 500 L.E.; Acacia Saligne = 500 L.E.; Treated wheat straw $=710$ L.E.; Kg live body weight of lambs $=50$ L.E.

\section{Statistical analysis:}

Data were statistically analyzed using OneWay Layout with Means Comparisons Procedure SAS (2003).

\section{RESULTS AND DISCUSSION}

Chemical composition and cell wall constituents:

The chemical composition and cell wall constituents of experimental rations are presented in Table (4). It was noticed that berssem hay contained more OM (88.53 vs, 87.91 and 87.23 , respectively) compared with the combination of two fodder tree with wheat straw ammoniated. Similarly, NFE (51.97 vs. 45.79 and 39.79 , respectively). Contrary, it was less in EE (3.21 vs. 3.75 and 4.22, respectively) and Ash (11.47 vs. 12.09 and 12.77, respectively). The differences in $\mathrm{CP}$ and $\mathrm{CF}$ were of fewer values. Moreover, the NDF and hemicellulose contents were increased while cellulose and ADL was decreased in the combination of two fodder tree with treated wheat straw than berseem hay. The chemical composition obtained by this study were nearly similar to that obtained by Ben Salem et al. (2005), Fulkerson et al. (2008) and Afaf et al. (2010) on berssem hay. Shaker et al. (2014) on some salt tolerant fodder shrubs mixture. The non fiber carbohydrates (NFC) were ranged from 28.81 to $47.61 \%$ in the presented experimental rations. Wheeler, (2003) reported that, the NFC levels in the total ration dry matter should not fall bellow 20 to $25 \%$ nor go above 40 to $45 \%$. Rations formulated for 35 to $37 \%$ NFC (DM basis) should avoid metabolic disturbances.

The levels of ANF's (anti-nutritional factors) are varied from plant to plant and from season to season (El-Shaer et al., 2005). The CT concentration for above optimum combinations was ranged on average from 20 to $30 \mathrm{~g} / \mathrm{kg} \mathrm{DM}$. The ideal CT concentration for ruminant nutrition has been suggested to be in the range 20 to $40 \mathrm{~g} / \mathrm{kg} \mathrm{DM}$, increase the absorption of essential amino acids from small intestine and increased wool growth, milk secretion and reproductive rate without affecting voluntary feed intake, thus improving the efficiency of food conversion, Kumar (2003).

\section{Methane production:}

Methane production indicates an energy loss to ruminant and many tropical feedstuffs have been implicated to increase methanogenesis as an integrated part of carbohydrate metabolism (Babayemi and Bamikole, 2006). Data of 
methane production are presented in Figure (1). The results indicated that the methane production with first combination Cassava: Acacia Saligne: treated wheat straw 37.5: 37.5: 25 less than second combination Cassava: Prosopis: treated wheat straw 37.5: 37.5: 25 (8 vs. $10 \mathrm{ml} / 200 \mathrm{mg}$ $\mathrm{DM}$, respectively). Whereas, first combination was contained more condensed tannins (CT) compared with second combination (30 vs. 20 $\mathrm{g} / \mathrm{kg} \mathrm{DM}$, respectively). In recent study, Eissa et al. (2015) they found that the rations consisted of
Cassava or Prosopis with ammoniated wheat straw. The methane production was more with Cassava than Prosopis (12 vs. $10 \mathrm{ml} / 200 \mathrm{mg}$ DM, respectively). It means, that the mixing between different types of shrubs to contain condensed tannins have been shown to decrease methane production both in vivo and in vitro. So, it is beneficial for sparing of energy loss as methane (Waghorn et al., 2002).

Table 4. Chemical composition, cell wall constituents and phenols compounds of experimental ratios

\begin{tabular}{|c|c|c|c|}
\hline \multirow{2}{*}{ Item } & \multicolumn{3}{|c|}{ Groups } \\
\hline & G1 & G2 & G3 \\
\hline $\mathrm{DM}$ & 91.58 & 75.30 & 73.50 \\
\hline \multicolumn{4}{|l|}{ Chemical composition: } \\
\hline $\mathrm{OM}$ & 88.53 & 87.91 & 87.23 \\
\hline $\mathrm{CP}$ & 14.61 & 14.52 & 15.40 \\
\hline $\mathrm{CF}$ & 42.21 & 43.20 & 41.23 \\
\hline $\mathrm{EE}$ & 3.21 & 3.75 & 4.22 \\
\hline NFE & 28.50 & 26.44 & 26.38 \\
\hline Ash & 11.47 & 12.09 & 12.77 \\
\hline \multicolumn{4}{|c|}{ Fiber fraction $\%$ of DM: } \\
\hline NDF & 32.10 & 32.40 & 38.80 \\
\hline $\mathrm{ADF}$ & 26.00 & 20.00 & 28.00 \\
\hline Hemi-cellulose & 6.10 & 12.40 & 10.80 \\
\hline Cellulose & 16.00 & 12.50 & 11.20 \\
\hline ADL & 10.00 & 7.50 & 6.80 \\
\hline NFC* & 38.61 & 37.24 & 28.81 \\
\hline $\mathrm{NFC/NDF}$ & 1.20 & 1.15 & 0.74 \\
\hline \multirow{2}{*}{\multicolumn{4}{|c|}{$\begin{array}{l}\text { Phenols compounds } \mathrm{g} / \mathrm{kg} \\
\text { DM: }\end{array}$}} \\
\hline & & & \\
\hline $\mathrm{TP}$ & 16.7 & 38.5 & 42.28 \\
\hline TT & 2.8 & 15.5 & 19.2 \\
\hline CT & 0.2 & 30 & 20 \\
\hline
\end{tabular}

* Non fiberous carbohydrates\%= OM\% - (CP\%+NDF\%+EE \%), Calsamiglia et al., 1995.

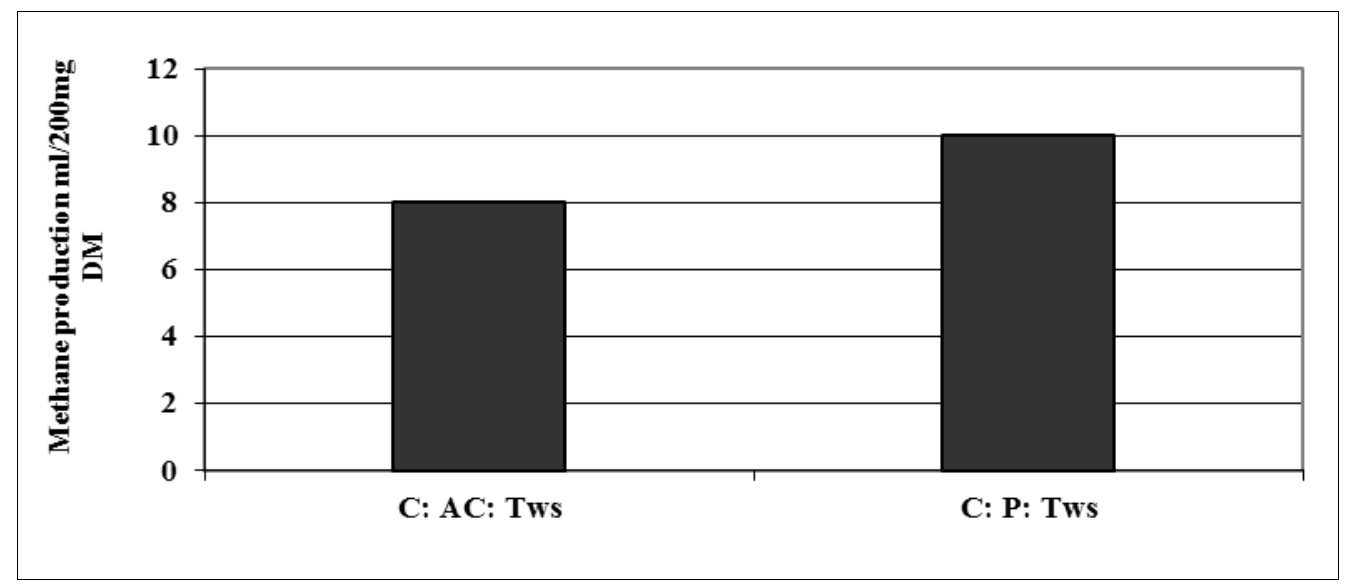

Fig. 1. Methane production from the experimental combination

\section{Blood parameters:}

Data of blood serum parameters are presented in Table (5). The results indicated that most tested blood parameters were not significantly affected by tested rations. However, serum total protein (TP), albumin (A) and globulin $(\mathrm{G})$ concentrations were tended to decrease with G2 and G3 compared with G1, but $\mathrm{A} / \mathrm{G}$ ratio was increase with the combination of two fodder tree with wheat straw ammoniated 
(G2 and G3) without significant differences. While, glucose, serum urea, cearatinine and cholesterol were significantly higher $(\mathrm{P}>0.05)$ with (G1) berseem hay $(60.10,46.26,1.95$ and 72.08, respectively) in Barki lambs rations. These findings were in accordance with reported by Asker (1998) and Abdel- Halim (2003). Moreover, Shaker et al. (2008) working on growing Barki lambs and Badawy et al. (2002) on growing Barki lambs and Baladi kids reported that feeding fresh acacia lowered TP, A and G values. This reduction of TP in animals fed salt shrubs might be owing to the high content of tannins in these plants. In agreement, Muller et al. (1989) and Reed et al. (1990) reported that high content of tannins in acacia probably decreases the digestibility of crude protein. Coles (1986) found that poor absorption of dietary constituents from the intestinal tract leads to hypoproteinemia. Tannins can reduce digestibility of protein and carbohydrate by inhibiting digestive enzymes and by altering permeability of the gut wall (Streeter et al., 1993). Moreover, Ortiz et al. (1993) reported that tannins could adversely influence digestibility and absorption of nutrients such as proteins and amino acids, carbohydrates and lipids and also the activity of digestive enzymes. The results were in harmony with those reported by Ismail et al. (2003) and Shaker et al. (2008).

The results indicated also small fluctuations among groups fed different rations in concentrations of ALT, calcium and phosphorus without significant, but the differences were significant with AST (Table 5). The highest values of triglyceride were recorded with $\mathrm{G} 2$ and G3 compared with G1 (39.83, 38.30 vs. 29.50 $\mathrm{u} / 1$, respectively) as shown in Table (5). Generally, the obtained results indicated that blood components measured were showed slightly differences among treatments tested, yet all values were within the normal ranges as reported by Kaneko (1989) for healthy goats and in line with findings of Shaker et al. (2014) when used salt tolerant fodder shrubs Mixture on physiological performance in small ruminant rations.

Table 5. Effect of feeding experimental rations for Barki lambs on some blood serum parameters

\begin{tabular}{|c|c|c|c|}
\hline \multirow{2}{*}{ Items } & \multicolumn{3}{|c|}{ Groups } \\
\hline & $\mathbf{G}_{1}$ & $\mathbf{G}_{2}$ & $\mathbf{G}_{3}$ \\
\hline Glucose , mg/dl & $60.10 \pm 1.65^{\mathrm{a}}$ & $48.22 \pm 0.32^{b}$ & $46.35 \pm 2.14^{b}$ \\
\hline Total protein, $\mathrm{g} / \mathrm{dl}$ & $7.11 \pm 0.43$ & $6.28 \pm 0.07$ & $6.31 \pm 0.43$ \\
\hline $\operatorname{Albumin}(A), g / d l$ & $3.15 \pm 0.11$ & $2.97 \pm 0.38$ & $3.06 \pm 0.07$ \\
\hline Globulin $(G), g / d l$ & $3.96 \pm 0.45$ & $3.32 \pm 0.44$ & $3.33 \pm 0.44$ \\
\hline $\mathrm{A} / \mathrm{G}$ ratio & $0.82 \pm 0.11$ & $0.95 \pm 0.21$ & $0.95 \pm 0.13$ \\
\hline Urea, g/dl & $46.26 \pm 1.15^{\mathrm{a}}$ & $29.55 \pm 0.64^{\mathrm{c}}$ & $36.19 \pm 0.97^{b}$ \\
\hline Creatinine $\mathrm{mg} / \mathrm{dl}$ & $1.95 \pm 0.09^{\mathrm{a}}$ & $1.11 \pm 0.07^{\mathrm{b}}$ & $1.28 \pm 0.08^{\mathrm{b}}$ \\
\hline Cholesterol, $\mathrm{mg} / \mathrm{dl}$ & $72.08 \pm 0.24^{\mathrm{a}}$ & $45.78 \pm 0.86^{\mathrm{c}}$ & $58.68 \pm 1.23^{b}$ \\
\hline Triglycerides mg/dl & $71.32 \pm 0.40^{\mathrm{b}}$ & $78.68 \pm 1.08^{\mathrm{a}}$ & $78.50 \pm 1.38^{\mathrm{a}}$ \\
\hline AST, u/l & $29.50 \pm 0.90^{\mathrm{b}}$ & $39.83 \pm 0.27^{\mathrm{a}}$ & $38.30 \pm 1.05^{\mathrm{a}}$ \\
\hline ALT, u/l & $17.33 \pm 0.43$ & $18.99 \pm 0.61$ & $18.82 \pm 0.78$ \\
\hline Calcium, mg /dl & $11.58 \pm 0.30$ & $12.16 \pm 0.46$ & $11.84 \pm 0.46$ \\
\hline Phosphorus, mg/dl & $5.30 \pm 0.20$ & $4.50 \pm 0.50$ & $4.90 \pm 0.42$ \\
\hline
\end{tabular}

Means in the same raw with different superscripts differ significantly at $\mathrm{P}<0.05$.

Table 6. Growth performance of Barki lambs fed the experimental rations

\begin{tabular}{lccc}
\hline \multicolumn{1}{c}{ Items } & \multicolumn{3}{c}{ Groups } \\
\cline { 2 - 4 } & $\mathbf{G}_{\mathbf{1}}$ & $\mathbf{G}_{\mathbf{2}}$ & $\mathbf{G}_{\mathbf{3}}$ \\
\hline No. of lambs & 10 & 10 & 10 \\
Feeding period, weeks & 16 & 16 & 16 \\
Initial weight, (kg) & $12.28 \pm 0.25$ & $12.24 \pm 0.13$ & $11.53 \pm 0.35$ \\
Final weight, ( kg) & $33.52 \pm 0.55^{\mathrm{a}}$ & $34.44 \pm 0.31^{\mathrm{a}}$ & $31.33 \pm 0.18^{\mathrm{b}}$ \\
Total gain, (kg) & $21.24 \pm 0.38^{\mathrm{b}}$ & $22.20 \pm 0.21^{\mathrm{a}}$ & $19.80 \pm 0.27^{\mathrm{c}}$ \\
Daily body gain, $(\mathrm{g})$ & $177 \pm 3.18^{\mathrm{b}}$ & $185 \pm 1.72^{\mathrm{a}}$ & $165 \pm 2.22^{\mathrm{c}}$ \\
\hline
\end{tabular}

a-c Means in the same row with different superscripts differ significantly at $\mathrm{P}<0.05$.

\section{Growth performance:}

Performances of the growing Barki lambs in relation to different experimental groups are presented in Table (6) and Figure (2). The effect of the experimental rations on both final body weight $(\mathrm{FBW})$ and total body gain (TBG) were significant. Meanwhile, the highest values of FBW and TBG were recorded with G2 (34.44 and 22.20, respectively) and the lowest values was detected with $\mathrm{G}_{3}(31.33$ and $19.80 \mathrm{~kg}$, respectively). Whereas, $\mathrm{G}_{1}$ recorded medium values (33.52 and $21.24 \mathrm{~kg}$, respectively). Thus, 
the daily body gain (DBG) was significantly increased $(\mathrm{P}<0.05)$ in Barki lambs fed $\mathrm{G} 2$ than the other groups G1 and G3. Similarly, the mean final body weight and mean daily live body weight gain obtained in the present study were higher for Prosopis Juliflora. Similar trend have been reported by Ahmed et al. (2012). Moreover, Mahgoub et al. (2005) observed increased body weight when the basal diet of elephant grass for Omani sheep was supplemented with Prosopis Juliflora. The possible explanation for significant increase of growth rate in $\mathrm{G} 2$ refers to increase of DMI and CP intake and may be also to tannins which increase fiber and protein digestibility (Patra, 2012).

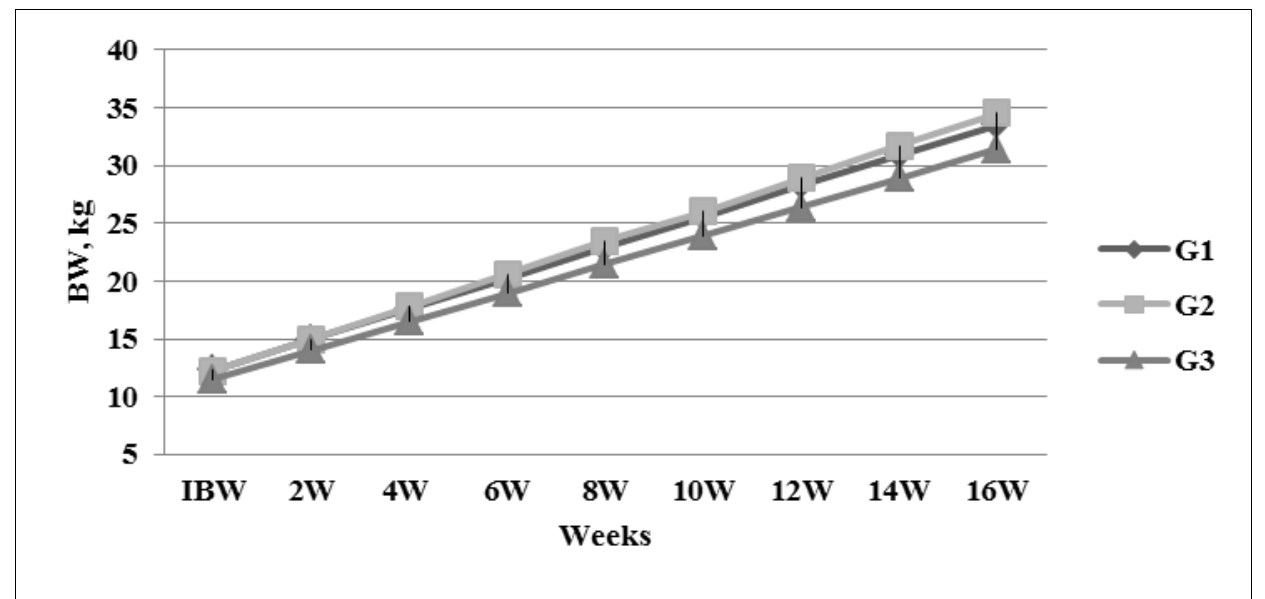

Fig. 2. Effect of experimental treatments on change in weight of Barki lambs.

\section{Feed intake and feed conversion:}

The low feeding level $662 \mathrm{~g} / \mathrm{h} / \mathrm{d}$ as DM with (G3) during experimental period had negative effects on total body gain $(19.80 \mathrm{~kg})$ and daily body gain $(165 \mathrm{~g})$ of lambs compared with the other groups Table (7). However, the highest level (G2) followed by (G1) 864 and 856, respectively. This result was in line with the results of other studies (Mahgoub et al., 2005; Abdullah et al., 2011). Abdullah et al. (2011) observed an increase in the total DM intake with an increase in supplementation with Prosopis Juliflora and sesame hulls. Data of feed conversion efficiency of the experimental lambs are summarized in Table7. The obtained results indicated that feed conversion calculated as dry matter intake and CP intake $/ \mathrm{kg}$ gain were better in G3 (4.01 and 0.618, respectively) compared with G2 (4.67 and 0.678, respectively) and G1 (4.84 and 0.707, respectively). The positive effect (based on DM and CP) obtained values of feed conversion are within the normal range given by Gabr et al. (1999) and El-Zalaky (2001).

\section{Economic efficiency:}

Economic efficiency (EE) estimated as price of gained weight divided by cost of feed consumed for that gain, are presented in Table (7). The results indicated that the highest economic efficiency was recorded with G2 (6.49\%) followed by G3 $(4.72 \%)$ and then for G1 (4.65\%). Similarly, Eissa et al. (2015) indicated that the economic efficiency was much better with supplementary values of tree fodder (Cassava or Prosopis) than berseem hay in growing Barki lambs rations. Norton (1994) stated that they had been incorporated into concentrate rations as substitutes for more expensive processed protein sources.

\section{CONCLUSION}

Under the semi-arid conditions, the combinations of Cassave and ammoniated wheat straw along with Prosopis Juliflora or Acacia Saligne (37.5: 37.5: 25; G2 and G3, respectively) could be included up to 60 percent in the complete diet of growing Barki lambs which increases the economic return without negative effect on growth performance and blood metabolites. 
Table 7. Feed intake, feed conversion and economic efficiency of Barki lambs fed the experimental rations

\begin{tabular}{lccc}
\hline \multicolumn{1}{c}{ Item } & G1 & Groups & G3 \\
\cline { 2 - 4 } & & G2 & 0 \\
\hline Daily feed intake, g/h/d & 514 & 0 & 149 \\
From berssem hay & 0 & 194 & 0 \\
From Cassava & 0 & 194 & 149 \\
From Prosopis Juliflora & 0 & 0 & 99 \\
From Acacia Saligne & 0 & 130 & 265 \\
From treated wheat straw & 342 & 346 & 662 \\
From CFM & 856 & 864 & 3.09 \\
Total DMI (g/h/d) & 3.74 & 3.70 & 66.47 \\
DMI as \% BW & 81.76 & 81.36 & 101.95 \\
DMI g/kg BW ${ }^{0.75}$ & 125.06 & 125.45 & 1.49 \\
CP intake (g/h/d) & 1.55 & 1.49 & $19.80 \pm 0.27 \mathrm{c}$ \\
Roughage: Concentrate (R/C) ratio & $21.24 \pm 0.38 \mathrm{~b}$ & $22.20 \pm 0.21 \mathrm{a}$ & \\
Total body gain, (kg) & Feed efficiency: & & 4.01 \\
& 4.84 & 4.67 & 0.618 \\
kg DM /kg gain & 0.707 & 0.678 & \\
kg CP/kg gain & & & 1.749 \\
Economic efficiency: & 1.904 & 1.425 & 8.25 \\
Cost of consumed feed, L.E/h & 8.85 & 9.25 & 4.72 \\
Price of weight gain, L.E & 10.76 & 7.70 & 6.49 \\
Feed cost/ kg gain, L.E & 4.65 & & \\
Economic efficiency, \% & & & \\
\hline Mat & & & \\
\hline
\end{tabular}

Market price (LE)/Ton fresh of ingredients:

$\mathrm{BH}=1600 \mathrm{LE} ; \mathrm{CFM}=2800 \mathrm{LE} ;$ Cassava $=500 \mathrm{LE} ;$ Prosopis Juliflora $=500 \mathrm{LE} ;$ Acacia Saligne $=500 \mathrm{LE} ;$

Treated wheat straw $=710 \mathrm{LE} ; \mathrm{Kg}$ live body weight of lambs $=50 \mathrm{LE}$.

a-c Means in the same row with different superscripts differ significantly at $\mathrm{P}<0.05$.

\section{REFERENCES}

A.O.A.C., 1995. Association of Official Analytical Chemists. Official Methods of Analysis. $15^{\text {th }}$ Ed., Washington DC.

Abdel- Halim, A. M., 2003. Studies of some antinutritional factors affecting utilization by ruminants. Ph. D. thesis, Faculty of Science, Ain Shams University.

Abdullah, Y.A, S.O. Belal, M.M. Marwan, K.M. Sulaiman and A.A. Majdi, 2011. Growth performance, carcass and meat characteristics of black goat kids fed sesame hulls and Prosopis julifl ora Pods. Asian-Aust. J. Anim. Sci. 24: 1217-1226.

Afaf M. Fayed, Abeer, M. El- Essawy, E.Y. Eid, H. G. Helal, Ahlam, R. Abdou and H. M. El Shaer., 2010. Utilization of alfalfa and atriplex for feeding sheep under saline conditions of South Sinai, Egypt. Journal of American Science, 6 (12): 1447- 1461.

Ahmed S. A., T. Sayan, R. Sarawut and K. Kriengki, 2012. Effect of Feeding Prosopis julifl ora Pods and Leaves on Performance and Carcass Characteristics of Afar Sheep. Kasetsart J. (Nat. Sci.) 46: $871-881$.

Askar, A. R. T., 1998. Effect of feeding some halophytic plants on nutritional and reproductive performance for growing sheep in Sinai. M. Sc. Thesis Faculty of Agriculture. Ain Shams University.

Babayemi, O.J. and M.A. Bamikole, 2006. Effects of Tephrosia candida DC leaf and its mixtures with Guinea grass on in vitro fermentation changes as feed for ruminants in Nigeria. Pak. J. Nutr., 5: 14-18.

Badawy, M. T., H. A. Gawish and A. A. Younis, 2002. Some physiological responses of growing Barki lambs and Baladi kids fed natural desert shrubs. International Symposium on Optimum Resources Utilization in Salt - Affect Ecosystems in Arid and Semi- arid Regions. Cairo, 8- 11, April, 496- 503.

Ben Salem, H., A. Nefzaoui, H. P. S. Makkar, H. Hochlef, I. Ben Salem and L. Ben Salem, 2005. Effect of early experience and adaptation period on voluntary intake, digestion and growth in Barbarine lambs given tannin - containing (Acacia cyanophylla Lindl. foliage) or tannin - free (oaten hay) diets. Anim. Feed Sci. and Tech. $122,59-77$.

Calsamiglia, S., M. D. Stern and J. L. Firkins , 
1995. Effects of protein source on nitrogen metabolism in continuous culture and intestinal digestion in vitro. J. Anim. Sci., 73: 1819.

Coles, E. H., 1986. Veterinary Clinical Pathology. $4^{\text {th }}$ Ed. Sunders W. B. Co., Philadelphia, London.

Degan, A.A., A. Blankc, K. Beker, M. Kam, R.W. Benjamin, H.P.S. Makkar, 1997. The nutritive value of Acacia saligna and Acacia saligna for goats and sheep. J. Anim Sci., 64: 253-259.

Eissa, M. M., EL. A, EL-Wakeel, A. M. Saber, A. R. Khattab and W. M. A. Sadek, 2015. Impact of feeding different combination of some fodder trees and treated crop residues on Barki lambs performance under semi-arid area in Egypt. (under publishing).

El-Shaer, H. M., Ali F.T., N.Y.S. Morcos, S.S. Emam and A.M. Essawy, 2005. Seasonal changes of some anti-nutritional factors contents of some halophytic shrubs and the effect of processing treatments on their utilization by sheep under desert conditions of Egypt. Egyptian J. Nut \& Feeds, 8 (1) Speciallssue:417-431.

El-Zalaky, O. A., 2001. Nutritional studies in ruminant "performance and some blood constituents of lactating goats fed diets containing either formaldehyde treated or untreated dried poultry manure" Ph.D. Thesis, Fac. Agric., Mansoura Univ.

Fulkerson, W. J., A. Horadagoda, J. S. Neal, I. Barchia, K. S. Nandra, 2008. Nutritive value of forage species grown in the warm temperate climate of Australia for dairy cows: Herbs and grain crops. Livest. Sci., 114: 75-83.

Gabr, A.A., A.Z. Mehrez, E.S.M. Soliman and M. El-Kholany, 1999. Response of lactating goats to diets containing reed grass (Aroundo domax L.) versus sorghum plants, Egyptian J. Nutrition and feeds , 2 ( special Issue), 297.

Harborne J.B., 1973. Phytochemical Methods, Chapman and Hall, Ltd., London, pp. 49-188.

Ismail, E., M. M. Anwar and S. S. Aboul ELEzz, 2003. Change in some blood constituents in sheep fed on rations containing Acacia saligna irrigated naturally or on sewage water. Alex. J. Agric. Res. 48 (3): 35- 40 .

Khang, D.N., H. Wiktorsson and T.R. Preston., 2005. Yield and chemical composition of cassava foliage and tuber yield as influenced by harvesting height and cutting interval. Asian-Australalian Journal of Animal Sciences 18, 1029-1035.

Kumar, R., 2003. Anti-nutritive factors, the potential risks of toxicity and methods to alleviate them. http:// www.fao.org/DOCREP/003/T0632E/T0632E 10.htm.

Mahgoub, O., I.T. Kadim, E.H. Johnson, A. Srikandakumar, N.M. Al-Saqri, A.S. Al-Abri, and A. Richie, 2005. The use of concentrate diet containing Meskit (Prosopis juliflora) pods and date palm by-products to replace commercial concentrate diets of Omani sheep. Anim. Feed Sci. Technol. 120: 33-41.

Makkar H.P.S., 2003. Effects and fate of tannins in ruminant animals, adaptation to tannins, and strategies to overcome detrimental effects of feeding tannin-rich feeds. Small Ruminant Research 49: 241- 256.

Muller, H. M., E. Leinmuller and U. Rittner, 1989. Effect of tanniferous plant material on protein and carbohydrate degradation in rumen fluid in vitro. In Recent Advance of Research. In Antinutritional Factors in Lequme Seeds. (Huisman, J.; Van der Poel, T. F. B. and Liener, I. E. eds.), pp. 156- 159, Wageningen.

Norton B. W., 1994. Tree Legumes as dietary supplements for ruminants, pp: 192-201. In Gutteridge R. C and H. M. Shelton: Forage tree legumes in tropical agriculture. CAB International.

NRC, 1985. Nutrient requirements of domestic animals. Nutrient requirements of sheep. National Research Council, Washington.

Ortiz, L. T., C. Centeno and J. Tervino , 1993. Tannins in faba bean seeds: effect on the digestion of protein and amino acids in growing chicks. Animal Feed Science and Technology, 41: 271- 278.

Oshodi A.A., 1992. Proximate composition, nutritionally valuable minerals and functional properties of Adenopus breviflorus benth seed flour and protein concentrate. Food Chem., 45, 79-83.

Patra A.K., D.N. Kamra and N. Agarwal, 2006. Effect of plants containing secondary metabolites on in vitro methanogenesis, enzyme profile and fermentation of feed with rumen liquor of buffalo. Anim. Nutr. Feed. Technol. 6, 203-213.

Patra, A.K., 2012. Enteric methane mitigation technologies for ruminant livestock: a synthesis of current research and future directions. Environmental Monitoring and Assessment. 184:1929

Reed J. D., 1995. Nutritional toxicology of tannins and related polyphenols in forage legumes. J. Anim. Sci. 73:1516-1528.

Reed J.D., C. Krueger, G. Rodriguez and J. Hanson, 2000. Secondary plant compounds and forage evaluation. In:Givens, D.I., Owen, E., Axford, R.F.E., Omed, H.M. (Eds.), Forage Evaluation in Ruminant Nutrition. CABPublishing, Wallingford, UK, pp. 433448.

Reed, J. D., H.Soller and A.Woodward, 1990. 
Fodder tree and straw diets for sheep: intake, growth, digestibility and the effects of phenolics on nitrogen utilization. Anim. Feed Sci. Tecknol. 30: 39.

SAS Institute, 2003. SAS/STATR User's Guide: statistics. Ver. 9.1, SAS Institute Inc., Cary, NC, USA.

Shaker, Y. M., S. S. Abou El-Ezz and A. L. Hashem, 2008. Physiological performance of Barki male lambs fed halophytes under semiarid conditions. J. Agric. Sci. Mansoura Univ., 33 (9): 6393- 6408.

Shaker, Y.M.1, N.H. Ibrahim, F. E. Younis, and H.M. El Shaer, 2014. Effect of feeding some salt tolerant fodder shrubs mixture on physiological performance of Shami goats in Southern Sinai, Egypt. Journal of American Science, 10 (2s): 66- 77.

Shawket, M.S., 1999. Effect of energy level supplementation on the utilization of some pasture plants by goats. J. Agric. Sci. Mansoura Univ., 24: 4565-4573.

Streeter, M. N., G. M. Hill, D. G. Wagner, F. N. Owens and C. A. Hibberd, 1993. Effect of bird resistant and non bird resistant sorghum gain on amino acid digestion by beef heifers. J. Anim. Sci., 71: 1648- 1656.

Van Soest P.J., 1965. Symposium of factors influencing the voluntary intake in relation to chemical composition and digestibility. J. Anim. Sci. 24:834.

Waghorn G.C., M.H. Tavendale and D.R. Woodfield, 2002. Methanogenesis in forages fed to sheep. In Proc. New Zealand Grassland Association Sixty-fourth Conference, West Coast, New Zealand, 5-7 November. 64, 167171.

Wheeler, B., 2003. Guidelines for feeding dairy cows. Ministry of Agriculture and Food, Government of Ontario, Canada.

Wilson A.D., 1992. Halophytic plants communities in Australia: Ecology and potential as a rangeland resource. Proc. Inter. Workshop. Halophytes as a resource for livestock and for rehabilitation of degraded land.

\title{
إستجابة الحملان البرقى المغذاة على علائق تحتوى على الكسـافاو تبن القمـح المعامل مـع (عيدان و أوراق)

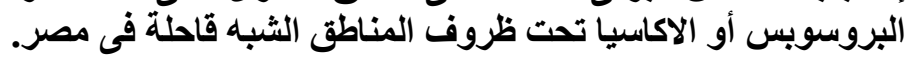

\author{
محمد محمد عيسى، وليد ماهر أمين، أحمد رجب خطاب \\ معهل بحوث الاتتاج الحيوانس، مركز البحوث الزراعية، الدقى، الجبيزة، مصر
}

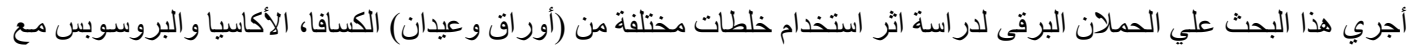

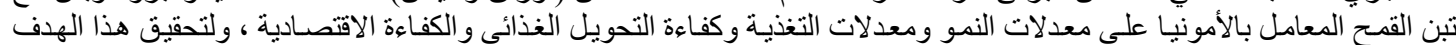

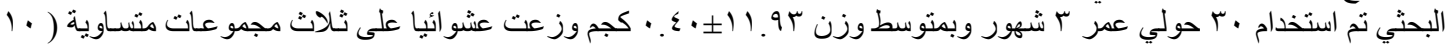

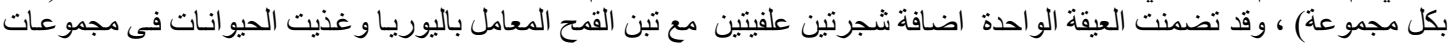

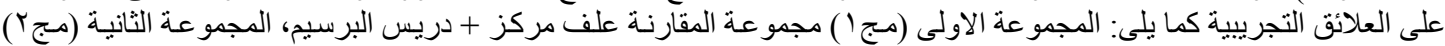

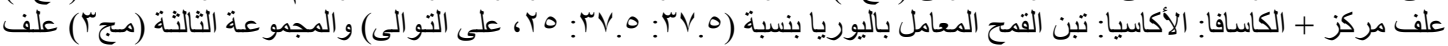

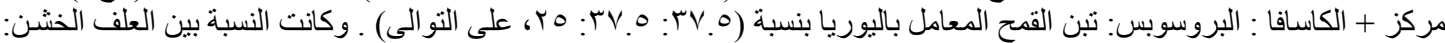

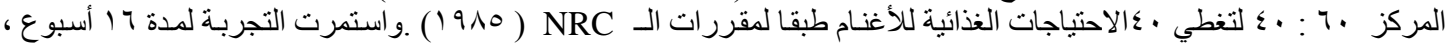

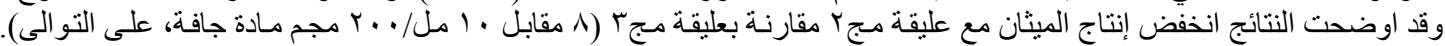

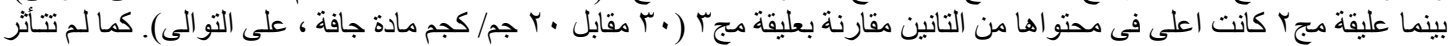

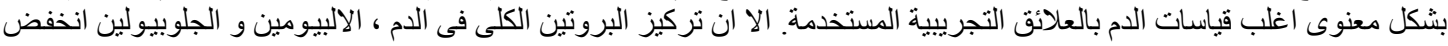

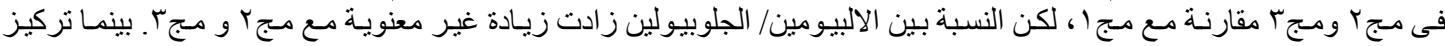

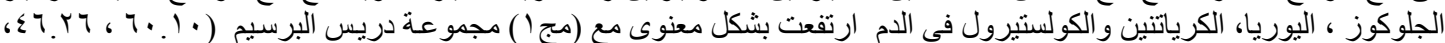

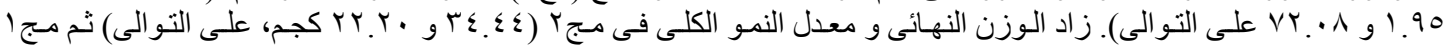

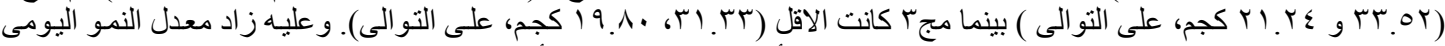

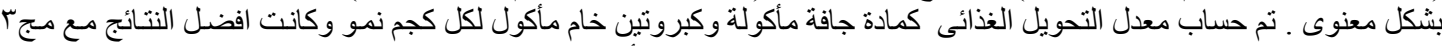

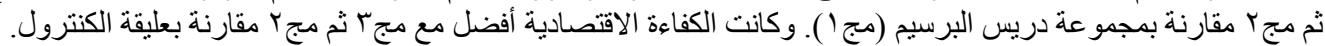

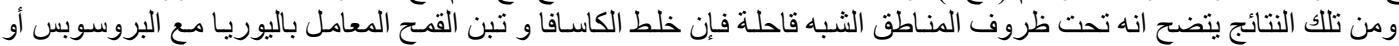

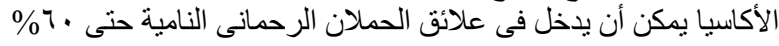

